\title{
Analysis of the citation impact of national journals toward SCIE journals on JCR ranking
}

\author{
Byungkyu Kim ${ }^{1}$, Youngseek Kim² and Jihoon Kang ${ }^{3 *}$ \\ ${ }^{1}$ Korea Institute of Science and Technology Information, \\ Department of Data-Centric Problem Solving Research \\ 245 Daehak-ro, Yuseong-gu, Daejeon, 34141, SOUTH KOREA \\ ${ }^{2}$ School of Information Science, University of Kentucky \\ 331 Little Library Building \\ Lexington, KY 40506, UNITED STATES \\ ${ }^{3}$ Chungnam National University \\ Department of Computer Science and Engineering \\ Rm. 505, 5 Engineering Building \\ 99 Daehak-ro, Yuseong-gu, Daejeon 34134, SOUTH KOREA \\ e-mail: bk.kim@kisti.re.kr; youngseek.kim@uky.edu; \\ *jhkang@cnu.ac.kr (corresponding author)
}

\begin{abstract}
The prior studies in the citation analyses of Korean natural science and engineering journals found that they have cited SCIE (Science Citation Index Extended) journals significantly. This research investigated the citation impact of the Korean natural science and engineering journals (from 2009 to 2014) toward SCIE journals in terms of JCR (Journal Citation Reports) ranking changes. First, this research analyzed the cited numbers and citation age by subject and journal through the citation analysis of the cited SCIE journals. Second, this research created the co-citation networks of journals and subjects by using co-citation analysis of SCIE journals. Based on the same method, we also assessed the network centrality measures and compared the citation numbers in each journal. Third, this research analyzed the changes in journal ranking in SCIE journal citation index by reflecting the citations of Korean natural science and engineering journals into JCR. Our results indicate that engineering has higher cited numbers, smaller peak-time, and cited half-time values than natural science. These results mean the journal articles in engineering are more quickly consumed and decreased than natural science journals, respectively. Second, this research visualized the co-citation network of SCIE journals and subject areas based on the Korean journals, and it also measured the network centrality in journals and subjects. Third, this research found that the existing journal Impact Factor (IF) (2 years) has been changed significantly if we apply the Korean journal citations into JCR in 2014, and there are significant changes in JCR journal rankings in engineering and natural science. This research shows the impact of Korean journals on SCIE journals, and the results of this study can be used for the future evaluation of journals. The practical implications were presented for Asian countries as well as Korea to develop their own JCR rankings and for their academic libraries to provide better scholarly services.
\end{abstract}

Keywords: Korea scholarly journals; Citation analysis; Journal co-citation analysis; Social network analysis; Science Citation Index; Journal Citation Reports 


\section{INTRODUCTION}

Web of Science (WoS) provides information services about citation indexes for the major journals. The WoS citation index databases are categorized into Science Citation Index Expanded (SCIE), Social Science Citation Index (SSCl), Arts \& Humanities Citation Index $(\mathrm{A} \& \mathrm{HCl})$ depending on disciplines, and in each category provides the Journal Citation Reports (JCR), including diverse citation indexes based on inter-journal citation index. The concept of SCIE was initially proposed by Eugene Garfield in 1955, and the Impact Factor (IF) of JCR has been used to assess the qualities of journals (Garfield 2006). The SCIE has included the major journals in science-engineering areas, and the journals in SCIE are considered critical journals in each discipline by research institutions and researchers. Researchers usually refer to SCIE journal articles for writing their own research papers, and they also have tried to publish their articles in the SCIE journals. As of recently, Google Scholar includes the WoS citation information and extends its usage for developing journal and author rankings.

According to International Monetary Fund (IMF), in 2014 the Republic of Korea ranked 13th in the world economy. According to Organization for Economic Co-operation and Development (OECD) in 2017, the Republic of Korea ranked 1st in terms of the ratio of Research \& Development (R\&D) investment out of GDP among OECD countries. This large investment in R\&D led to the increase of the production of research articles and their citations by Korean journals, and therefore, the Republic of Korea is now perceived as the emerging research-production center of the world (Leydesdorff and Zhou 2005). According to a SCIE article survey in science-engineering (So 2015), the Republic of Korea ranked 12th in terms of the number of publications in SCIE, and ranked 13th in number of citations. Kim, So and Choi (2014) analyzed the percentage of article publications in diverse disciplines, and found that natural science and engineering disciplines produced more than 70 percent of the entire articles published in the Korean journals including: Biomedical Sciences (18\%), Chemistry (17\%), Material Sciences (13\%), Computer Sciences (12\%), and Clinical Medicine (11\%) (Kim, So and Choi 2014). According to JCR in 2014, the Republic of Korea has a total of 102 SCIE journals, and according to the Korea Institute of Science and Technology Information (KISTI) survey on List of Korean Natural Science and Engineering Journal, in August 2015, the Republic of Korea has a total of 1,160 primary journals (Kang and Kim 2015). Based on prior studies on the citation trend in the Korean journals, Korean natural science and engineering journals have cited international (other countries) journals heavily, and especially, the portion of SCIE journals is very high.

This research analyzed the citation impact of national journals toward SCIE journals on JCR by sampling natural science and engineering journals published in Korea. For the analysis, this research employed the Korea Science Citation Database (KSCD) by KISTI as the data source. KSCD has the Korean natural science and engineering primary journals in all research areas, and especially, it has the important Korean journals in the areas of natural science and engineering. This research focuses on the natural science and engineering journals for its reliable SCIE citation impact analysis. In this research, the field of natural science includes: Biological Sciences, Earth \& Environmental Sciences, Chemistry, Physics, Mathematics, and Computer \& Information Sciences. Also, the field of engineering includes Electrical \& Electronic Engineering, Mechanical Engineering, Chemical Engineering, Materials Engineering, Civil Engineering, and Environmental Engineering. This research employed the Korean Science and Engineering Citation Index ( $\mathrm{KSCl}$ ) service based on the KSCD. It utilized three different methods to analyze the citation impact of national journals toward SCIE journals. Firstly, it examined cited numbers and citation age in subject areas and journals through cited SCIE journal citation analysis. Secondly, it created co-citation network of 
journals and subject areas by using SCIE journal co-citation analysis. The research also assessed the network centrality measures of each journal by using Gephi, a social network analysis tool, and compared the number of citations of each journal (Bastian, Heymann and Jacomy 2009). Additionally, this research visualized the map of science citations based on the co-citation frequency matrix (the journal-to-journal co-citation frequency matrix) by using a network visualization tool, VOSviewer (Van Eck and Waltman 2010). Third, the study analyzed the changes of journal rankings by recalculating the IF ( 2 years) of the major SCIE journals in natural science and engineering by reflecting the citation records of Korean journals for SCIE journals into the existing JCR. The structure of this paper includes report on prior studies of related research area, discusses the research method, and presents the results.

\section{LITERATURE REVIEW}

After the 1960s, diverse citation analysis methods such as bibliographic coupling analysis and co-citation analysis have been developed. In bibliographic coupling analysis, two or more articles are considered to have similar subjects if they have the same articles cited, and for the unit of analysis, article and author combinations were developed and used for bibliographic coupling analysis (Kessler 1963; Zhao and Strotmann 2008). In co-citation analysis, any frequently co-cited articles are considered to be very relevant, and depending on the unit of analysis, article-author co-citation analysis, article co-citation analysis, and subject co-citation analysis have been developed and used so far (Marshakova 1973, Small 1973; White and Griffith 1981; McCain 1991). Apart from citation relationship, co-word analysis method has been developed and utilized for co-author relationship and keyword relationship analyses (Liu, Hu, and Wang 2012). Small and Garfield (1985) developed the global map of science based on the co-citation analysis in SCIE and SSCl database, and scholars have worked on the knowledge organization analysis in disciplines based on the map of science (Boyack, Klavans and Börner 2005).

Additionally, the network centrality analysis based on the social network analysis has been applied for citation analysis. The core concepts of network centrality include degree centrality, betweenness centrality, and closeness centrality (Freeman 1978). The centrality of the connection level is calculated by the sum of the direct connections from a node. The centrality of the connection level is measured by any nodes which are closely connected (i.e., less than two levels), so it provides a somewhat limited centrality. Therefore, it is an appropriate measurement for the local centrality. The closeness centrality is defined as the sum of the shortest paths between one node and the other nodes, and it can find the most central node in a network which is the shortest path among all the nodes. Therefore, it is a useful measurement for examining the global centrality. The betweenness centrality is measured by the position level of one node among other nodes, and any nodes which have high betweenness centrality can mediate with other group of nodes. Leydesdorff and Zhou (2005) found that the betweenness centrality can be used to measure academic relationships (Dolfsma and Leydesdorff 2008). There are a number of Social Network Analysis tools such as Pajek and UCINET, and recently Gephi and VOSviewer, which are heavily utilized for the social network analysis due to their visualization methods.

A number of Asian countries have developed their own citation indexes for the purpose of their journal citation analysis and evaluation, and those Asian country-based citation indexes include Malaysian Citation Index (MyCite) (Zainab et al. 2012), Thai-Journal Citation Index (TCI) (Sombatsompop et al. 2012), Chinese Science Citation Database (CSCD) (Jin and Wang 
1999), and Korea Science Citation Database (KSCD) (Choi et al. 2013). The China National Knowledge Infrastructure (CNKI), especially, also developed the Annual Report for International Citation of Chinese Academic Journals (CAJ-INCR) to measure the citation impact of international journals toward Chinese domestic journals (Wu et al. 2015). Since the early 2000, KISTI in the Republic of Korea has developed KSCD, which provides Korea Science Citation Index (KSCl) based on citation data from Korean natural science and engineering primary journals. KSCD includes the important journals in natural science and engineering, and it also includes a good number of medicine and pharmaceutical journals. Therefore, KSCD is the most appropriate platform to garner citation analysis in natural science and engineering fields.

A prior study on journal citation analysis based on $\mathrm{KSCl}$, the reference analysis from Korean journals, shows that Korean journal articles cite mostly other journals, followed by conference papers, book sections, and other reference types. This research also indicates that the number of international journal articles are higher than the number of domestic Korean journal articles (Choi et al. 2013). The most critical component from these analyses shows that SCIE and Scopus journal articles are among the most heavily cited international journal articles. In addition, the citation age analysis of international journals shows that the highest citation point by Korean natural science and engineering journals for the international journals is 3.5 years on average, and the citation half-time is 9 years on average (Choi et al. 2013).

Compared to the studies focusing on Korean journals and their impacts on JCR, other scholars also investigated how national journals influence the existing JCR Impact Factor (IF) and its ranking. Miguel-Dasit et al. (2005) reported how Spanish health science journals that were not registered in JCR, had affected the IFs of the radiological journals registered in JCR; they found that the IFs of the radiological journals in JCR had increased, especially in European journals rather than U.S. journals. Aleixandre-Benavent et al. (2007) also found that the Spanish health science journals that were not registered in JCR influenced the IFs of JCR journals by increasing the IFs of mostly U.S. and British journals. Comparatively, Wu et al. (2015) assessed the international influence of more than 6,000 Chinese journals, the results indicated some of the Chinese journals have strong international influences in terms of IF and citation counts.

Since Korean natural science and engineering journal articles cite SCIE journal articles heavily (Lee et al. 2012) re-calculated the journal IF index by combining the citation index of Korean computer engineering journals and JCR in 2010 and compared it to the prior index; they confirmed significant changes in journal ranking. However, its overall analysis of natural science and engineering disciplines was limited because the scope of analysis was restricted to those specific areas, and the KSCD collection was very narrow (Lee et al. 2012). Jo and Lee (2012) analyzed the citation trend of Korean pharmaceutical journals, and they found no significant relationships between the citation rankings of SCIE and JCR. Therefore, they suggested that the Korean citation index needs to be considered along with JCR for the appropriate evaluation of journals in research and application. Their study was limited, however, because it only focused on the Korean domestic pharmaceutical research areas rather than the entire science-engineering research areas (Jo and Lee 2012). As a result, this research has utilized the KSCD which was extended in the scope of journals and improved by the identification of journals, and it overcame the limitations of existing citation analysis studies and performed a comprehensive citation analysis in natural science and engineering research. 


\section{METHOD}

This research investigated the citation impact of Korean natural science and engineering journals toward SCIE journals in terms of JCR ranking changes. This research examined (a) the cited numbers and citation age by conducting citation analysis of the cited SCIE journals; (b) the co-citation networks of journals and subjects using co-citation analysis of SCIE journals; and (c) the changes in journal ranking in SCIE journal citation index by applying the citations of Korean journals into JCR. This research employed the KSCD of KISTI for analyzing the citation impact of national journals toward SCIE journals. In 2016, KSCD as KSCI service database had 550 thousand journal articles and 1.2 million references from 2002 to 2015. The experiment was conducted based on the SCIE journal articles cited by the Korean journal articles of natural science and engineering from 2009 to 2014 that were stored in KSCD.

Table 1 and 2 present the status of KSCD and the scope of the experiment for this research. This research utilized a total of 3,731,983 references in 192,168 journal articles in the 463 Korean natural science and engineering journals. Among the approximately 3.7 million references, there are 1,418,000 SCIE journal articles (i.e., about 38\%) included in 7,605 SCIE journals. This research used the Fields of Science Technology (FOS) of OECD and Science Category (SC) of WoS. We selected WoS for our analysis methods since it is the major scholarly information service that provides citation indexes. Additionally, WoS has ranked as highly credible with a large scope of citation indexed journals (Meho and Yang 2007). The OECD FOS categorizes the entire disciplines into 6 main categories and 42 sub-categories, and the WoS SC categorizes the science-engineering disciplines into 176 categories. We used both OECD FOS and WoS SC subject area mapping provided by the Web of Knowledge.

For the experiment method, first, we conducted the citation analysis and measured the citation age of cited SCIE journal articles by Korean journal articles. The citation age means the years spent for the citation after its original publication, and it is measured by the difference between the year cited and the year published. Based on the citation year, immediacy citation rate, peak-time of citation, and citation half-time can all be calculated. The Immediacy Citation rate is the number of citations in the year an article was published. Peak-Time was the year when the article was more heavily cited. The Cited Half-time is used to measure the life span of an article, and it is measured by the point where the aggregated number of citations reaches 50 percent among the total number of citations (Lee and Yoon 1996). Second, this research employed the co-citation analysis method of SCIE journals, so it developed the co-citation analysis network among journals and subject areas and eventually measured the centrality score and number of citations for each journal. For this analysis, we developed the program which creates a co-citation matrix, and we also employed Gephi and VOSviewer for visualizing the network centrality index and network itself. Third, we analyzed the effect of the IF ( 2 years) of the SCIE journals based on the citation records of Korean natural science and engineering journals on the ranking of SCIE journals compared to the existing IF index ranking. For this analysis, we utilized the citation records in 2014 from the KSCD in natural science and engineering (see Table 1 and 2 for experimental data) and the $2014 \mathrm{JCR}$ for SCIE published in 2015. This research employed the 2014 JCR report since it matches the citation records in 2014 from the KSCD in terms of time frame. We utilized the Pearson correlation coefficient for analyzing the relationship between the existing index and newly created index. Impact Factor (IF) is calculated by the average number of citations which refer to the articles published in a journal for two years. Specially, the IF is defined as: 
Kim, B., Kim, Y. \& Kang, J.

$A=$ Total number of citations from $(X-1)$ year and $(X-2)$ year by the designated journals for a Journal, $\mathrm{J}$, in $\mathrm{X}$ year

$B=$ Total number of citable items (i.e., published articles) from (X-1) year and (X-2) year in a Journal, $J$

IF of a Journal, J, in $\mathrm{X}$ year $=\mathrm{A} / \mathrm{B}$

Table 1: Status of KSCD (2009-2014) and Experiment Data Scope

(Natural Science and Engineering, 2009-2014)

\begin{tabular}{c|r|r|r|r}
\hline \multicolumn{7}{|c}{ KSCD Status (2009 2014) } \\
\hline $\begin{array}{c}\text { Years } \\
\text { Published }\end{array}$ & No. of Journals & No. of Articles & No. of References & $\begin{array}{c}\text { No. of SCIE Journal } \\
\text { Article Citations }\end{array}$ \\
\hline 2009 & 677 & 47,947 & 990,467 & 432,253 \\
\hline 2010 & 723 & 50,020 & $1,043,542$ & 439,002 \\
\hline 2011 & 738 & 51,661 & $1,112,063$ & 479,356 \\
\hline 2012 & 659 & 47,089 & $1,025,996$ & 433,584 \\
\hline 2013 & 650 & 48,209 & $1,075,475$ & 323,046 \\
\hline 2014 & 700 & 51,779 & $1,196,751$ & 525,795 \\
\hline Total & 850 & 296,705 & $6,444,294$ & $2,633,036$ \\
\hline
\end{tabular}

Experiment Scope : KSCD Natural Science and Engineering (2009 2014)

\begin{tabular}{|c|c|c|c|c|}
\hline $\begin{array}{c}\text { Years } \\
\text { Published } \\
\end{array}$ & $\begin{array}{c}\text { No. of Journals } \\
\text { (Natural Science) }\end{array}$ & No. of Articles & No. of References & $\begin{array}{l}\text { No. of SCIE Journal } \\
\text { Article Citations }\end{array}$ \\
\hline 2009 & 185 & 13,951 & 288,183 & 128,664 \\
\hline 2010 & 192 & 14,187 & 295,563 & 120,231 \\
\hline 2011 & 191 & 14,699 & 317,592 & 131,190 \\
\hline 2012 & 192 & 14,088 & 319,185 & 131,517 \\
\hline 2013 & 188 & 14,672 & 343,944 & 102,493 \\
\hline 2014 & 191 & 15,324 & 372,186 & 152,038 \\
\hline Sub-Total & 215 & 86,921 & $1,936,653$ & 766,133 \\
\hline $\begin{array}{c}\text { Years } \\
\text { Published }\end{array}$ & $\begin{array}{l}\text { No. of Journals } \\
\text { (Engineering) }\end{array}$ & No. of Articles & No.of References & $\begin{array}{c}\text { No.of SCIE Journal } \\
\text { Article Citations }\end{array}$ \\
\hline 2009 & 194 & 16,076 & 252,123 & 97,056 \\
\hline 2010 & 200 & 17,054 & 275,143 & 102,485 \\
\hline 2011 & 198 & 17,277 & 287,977 & 110,718 \\
\hline 2012 & 216 & 17,510 & 301,918 & 109,205 \\
\hline 2013 & 211 & 17,908 & 317,209 & 84,294 \\
\hline 2014 & 226 & 19,406 & 360,683 & 148,109 \\
\hline Sub Total & 248 & 105,231 & $1,795,053$ & 651,867 \\
\hline Grand Total & 463 & 192,152 & $3,731,706$ & $1,418,000$ \\
\hline
\end{tabular}


Table 2: Subject Areas of KSCD Natural Science and Engineering Journals (Data Scope: 2009-2014)

\begin{tabular}{|c|c|c|c|c|c|}
\hline $\begin{array}{c}\text { Main } \\
\text { Category }\end{array}$ & Sub Category & $\begin{array}{r}\text { No. of } \\
\text { Journals }\end{array}$ & $\begin{array}{r}\text { No. of } \\
\text { Articles }\end{array}$ & $\begin{array}{r}\text { No. of } \\
\text { References }\end{array}$ & $\begin{array}{l}\text { No. of SCIE Journal } \\
\text { Article Citations } \\
\end{array}$ \\
\hline \multirow{8}{*}{ 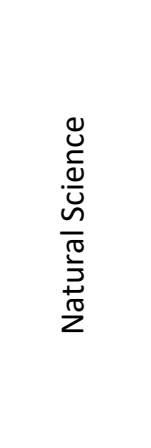 } & Mathematics & 22 & 8,653 & 150,322 & 47,941 \\
\hline & Computer \& Info. Sciences & 40 & 14,436 & 248,144 & 45,420 \\
\hline & Physical Sciences \& Astronomy & 18 & 8,721 & 159,562 & 96,051 \\
\hline & Chemical Sciences & 22 & 13,277 & 349,688 & 166,959 \\
\hline & Earth \& Related Environ. Science & 45 & 13,538 & 297,990 & 89,050 \\
\hline & Biological Sciences & 55 & 16,794 & 509,384 & 287,760 \\
\hline & Other Natural Sciences & 13 & 11,502 & 221,563 & 32,952 \\
\hline & Sub Total & 215 & 86,921 & $1,936,653$ & 766,133 \\
\hline \multirow{13}{*}{ 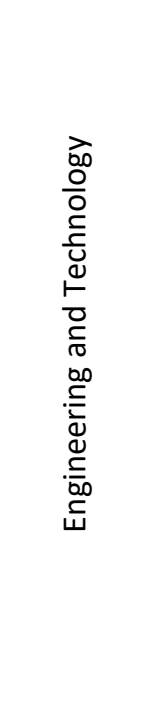 } & Civil Engineering & 44 & 13,646 & 241,042 & 61,700 \\
\hline & Electrical \& Electronic Eng. & 49 & 28,350 & 365,421 & 104,154 \\
\hline & Mechanical Engineering & 33 & 14,550 & 201,823 & 70,875 \\
\hline & Chemical Engineering & 5 & 2,181 & 45,682 & 17,838 \\
\hline & Materials Engineering & 31 & 14,406 & 291,659 & 137,212 \\
\hline & Medical Engineering & 6 & 1,892 & 45,305 & 28,774 \\
\hline & Environmental Engineering & 29 & 9,442 & 145,775 & 41,107 \\
\hline & Environmental Biotechnology & 6 & 3,517 & 105,159 & 57,523 \\
\hline & Industrial Biotechnology & 1 & 68 & 729 & 202 \\
\hline & Nano-Technology & 2 & 126 & 4,333 & 3,265 \\
\hline & Other Eng. \& Technologies & 42 & 17,053 & 348,125 & 129,217 \\
\hline & Sub Total & 248 & 105,231 & $1,795,053$ & 651,867 \\
\hline & Grand Total & 463 & 192,152 & $3,731,706$ & $1,418,000$ \\
\hline
\end{tabular}

\section{RESULTS}

\section{Citation Analysis of SCIE Journals in KSCD}

We conducted the citation analysis of the cited SCIE journals in Korean natural science and engineering journals based on the data scope and research methods in section 3 . First, we analyzed the citation status by published years and subject areas, and then we analyzed the citation speed by subject areas.

Figure 1 shows the total percentage of citations in each year for SCIE journal articles by the 463 Korean journals based on KSCD from 2009 to 2014. The green, blue, and red marks show the percentages of citations by Korean natural science, engineering, and both natural science and engineering journals, respectively. This graph shows that articles published from 1994 to 2014 were heavily cited by the Korean natural science and engineering journals.

Additionally, we reviewed the number of citations in the cited SCIE journals by 463 Korean natural science and engineering journals based on KSCD from 2009 to 2014, and our results indicated that among 7,603 SCIE journals, 311 journals have more than 1,000 citations and have more than 50 percent of the total citations. The top 20 most cited journals in natural 
science and engineering are presented in Appendix A, and the top 20 journals based on cocitation network centrality are presented in Appendix B.

Figure 1: Percentages of Citations Each Year for SCIE Journal Articles by the 463 Korean Journals based on KSCD from 2009 to 2014

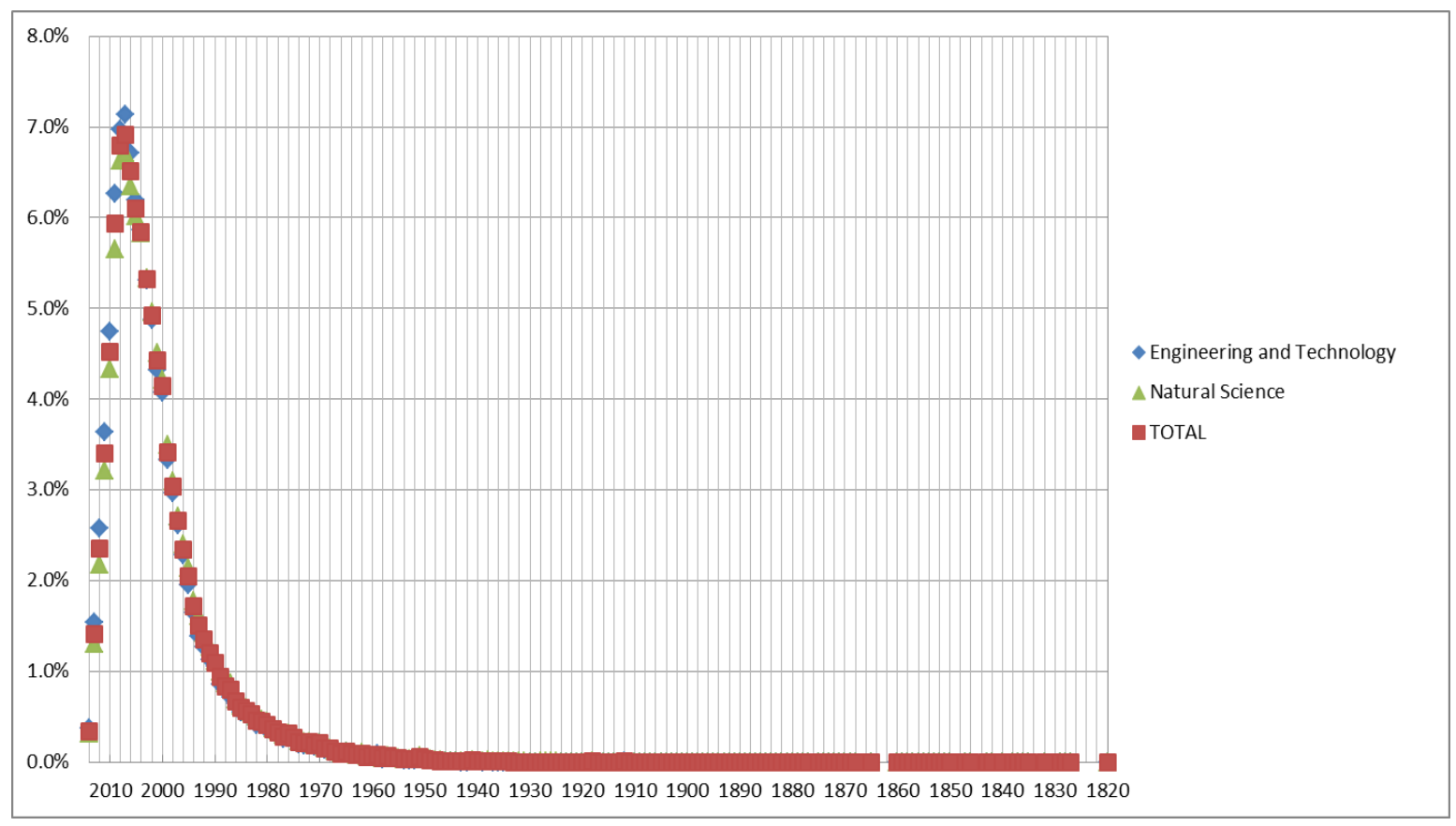

Table 3 presents the entire citation status categorized by OECD subject areas. The results show that the Korean natural science and engineering journals cite the SCIE natural science and engineering journals most often; however, they also cite other journals such as medicine, agriculture, and ocean studies. This is because the natural science and engineering journal articles usually refer to diverse areas of research. By investigating the natural science and engineering areas, natural science disciplines cite more journals and articles than engineering disciplines, however, engineering disciplines have more citation rates by journal (i.e., the number of citations by the number of journals) than natural science disciplines. Based on the mid-subject areas, Biological Sciences has the highest share rate $(13.3 \%)$ followed by Chemical Sciences (9.5\%) in natural science, and Materials Engineering has the highest share rate followed by Electronic Engineering in engineering.

The Korean natural science and engineering journals cite more than 80 percent of SCIE natural science and engineering journals. We calculated the citation age by consolidating journals into subject areas and produced Table 4, including immediacy citation rate, peaktime, and citation half-time. Since this research focuses on the citation point by Korean journals from 2009 to 2014, we calibrated the starting point of citation age for each year as 0 . The results show that engineering has high immediacy citation rate, citation peak-time, and citation half-time. This means that engineering journal articles are more quickly consumed and in decline than natural science journal articles. 
Table 3: Citation Status of SCIE Journals by 463 Natural Science and Engineering Journals based on KSCD from 2009 to 2014 (OECD Subject Category Citation Statistics) Main

\section{Category}

\begin{tabular}{|c|c|c|c|c|c|}
\hline & Mid Category & $\begin{array}{r}\text { No. of } \\
\text { Journals }\end{array}$ & $\begin{array}{r}\% \text { of } \\
\text { Journals } \\
\end{array}$ & $\begin{array}{r}\text { No. of } \\
\text { Citations }\end{array}$ & $\begin{array}{r}\% \text { of } \\
\text { Citations }\end{array}$ \\
\hline \multirow{8}{*}{ 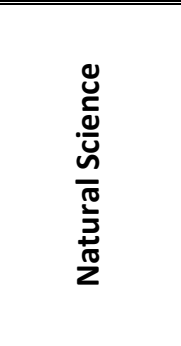 } & Mathematics & 557 & $7.324 \%$ & 59,687 & $4.209 \%$ \\
\hline & Computer \& Info. Sciences & 264 & $3.471 \%$ & 35,405 & $2.497 \%$ \\
\hline & Physical Sciences and Astronomy & 276 & $3.629 \%$ & 109,719 & $7.738 \%$ \\
\hline & Chemical Sciences & 356 & $4.681 \%$ & 134,960 & $9.518 \%$ \\
\hline & Earth \& Related Environ. Sciences & 476 & $6.259 \%$ & 91,534 & $6.455 \%$ \\
\hline & Biological Sciences & 1,067 & $14.030 \%$ & 188,671 & $13.305 \%$ \\
\hline & Other Natural Sciences & 42 & $0.552 \%$ & 29,879 & $2.107 \%$ \\
\hline & Sub Total & 3,038 & $39.947 \%$ & 649,855 & $45.829 \%$ \\
\hline \multirow{12}{*}{ 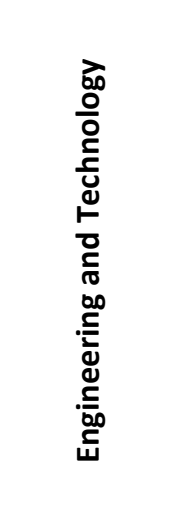 } & Civil Engineering & 123 & $1.617 \%$ & 50,893 & $3.589 \%$ \\
\hline & Electrical \& Electronic Eng. & 274 & $3.603 \%$ & 98,341 & $6.935 \%$ \\
\hline & Mechanical Engineering & 218 & $2.867 \%$ & 71,814 & $5.064 \%$ \\
\hline & Chemical Engineering & 82 & $1.078 \%$ & 37,013 & $2.610 \%$ \\
\hline & Materials Engineering & 264 & $3.471 \%$ & 107,715 & $7.596 \%$ \\
\hline & Medical Engineering & 71 & $0.934 \%$ & 7,311 & $0.516 \%$ \\
\hline & Environmental Engineering & 117 & $1.538 \%$ & 25,718 & $1.814 \%$ \\
\hline & Environmental Biotechnology & 100 & $1.315 \%$ & 33,245 & $2.344 \%$ \\
\hline & Industrial Biotechnology & 5 & $0.066 \%$ & 4,843 & $0.342 \%$ \\
\hline & Nano-Technology & 2 & $0.026 \%$ & 27 & $0.002 \%$ \\
\hline & Other Eng. \& Technologies & 269 & $3.537 \%$ & 80,686 & $5.690 \%$ \\
\hline & Sub Total & 1,525 & $20.053 \%$ & 517,606 & $36.503 \%$ \\
\hline \multirow{4}{*}{ 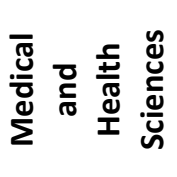 } & Basic Medical Research & 513 & $6.746 \%$ & 62657 & $4.419 \%$ \\
\hline & Clinical Medicine & 1,454 & $19.119 \%$ & 95,086 & $6.706 \%$ \\
\hline & Health Sciences & 518 & $6.811 \%$ & 28,636 & $2.019 \%$ \\
\hline & Sub Total & 2,485 & $32.676 \%$ & 186,379 & $13.144 \%$ \\
\hline \multirow{7}{*}{ 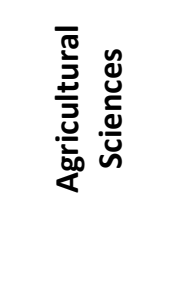 } & Agriculture, Forestry, Fisheries & 222 & $2.919 \%$ & 31,196 & $2.200 \%$ \\
\hline & Animal and Dairy Science & 42 & $0.552 \%$ & 7,087 & $0.500 \%$ \\
\hline & Veterinary Science & 107 & $1.407 \%$ & 5,473 & $0.386 \%$ \\
\hline & Other Agricultural Science & 19 & $0.250 \%$ & 6,375 & $0.450 \%$ \\
\hline & Sub Total & 390 & $5.128 \%$ & 50,131 & $3.535 \%$ \\
\hline & Psychology & 64 & $0.842 \%$ & 2,836 & $0.200 \%$ \\
\hline & Economics and Business & 39 & $0.513 \%$ & 9,848 & $0.694 \%$ \\
\hline \multirow{8}{*}{ 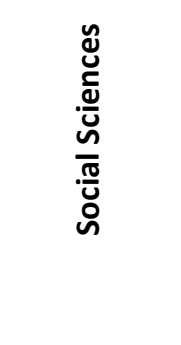 } & Educational Sciences & 29 & $0.381 \%$ & 1,084 & $0.076 \%$ \\
\hline & Sociology & - & - & - & . \\
\hline & Law & - & - & - & . \\
\hline & Political Science & - & - & - & . \\
\hline & Social and Economic Geography & - & - & - & - \\
\hline & Media and Communication & - & - & - & . \\
\hline & Other Social Sciences & - & - & - & . \\
\hline & Sub Total & 132 & $1.736 \%$ & 13,768 & $0.971 \%$ \\
\hline \multirow{7}{*}{ 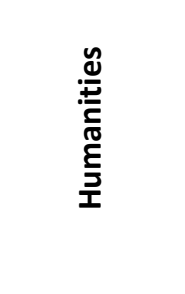 } & History and Archaeology & 35 & $0.460 \%$ & 261 & $0.018 \%$ \\
\hline & Languages and Literature & - & - & - & - \\
\hline & Philosophy, Ethics and Religion & - & - & - & - \\
\hline & Art & - & - & - & - \\
\hline & Other Humanities & - & - & - & 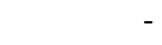 \\
\hline & Sub Total & 35 & $0.460 \%$ & 261 & $0.018 \%$ \\
\hline & Total & 7,605 & $100.000 \%$ & $1,418,000$ & $100.000 \%$ \\
\hline
\end{tabular}


Table 4: Immediacy Citation Rate, Citation Peak-Time, Citation Half-time in Natural Science and Engineering SCIE Journals (OECD Subject Category Citation Status) Main Category

\begin{tabular}{|c|c|c|c|c|}
\hline & Mid Category & $\begin{array}{r}\text { Immediacy } \\
\text { Citation } \\
\text { Rate }\end{array}$ & $\begin{array}{r}\text { Citation } \\
\text { Peak-Time }\end{array}$ & $\begin{array}{r}\text { Citation } \\
\text { Half-time }\end{array}$ \\
\hline \multirow{8}{*}{ Natural Science } & Mathematics & $1.0 \%$ & 3 & 11.4 \\
\hline & Computer and Information Sciences & $1.8 \%$ & 4 & 7.1 \\
\hline & Physical Sciences and Astronomy & $1.5 \%$ & 2 & 7.3 \\
\hline & Chemical Sciences & $1.4 \%$ & 3 & 6.7 \\
\hline & Earth and Related Environ. Sciences & $1.5 \%$ & 5 & 8.4 \\
\hline & Biological Sciences & $1.3 \%$ & 4 & 8.6 \\
\hline & Other Natural Sciences & $0.8 \%$ & 8 & 10.3 \\
\hline & Sub Total & $1.4 \%$ & 3 & 8.1 \\
\hline \multirow{12}{*}{$\begin{array}{l}\text { Engineering and } \\
\text { Technology }\end{array}$} & Civil Engineering & $1.9 \%$ & 4 & 6.2 \\
\hline & Electrical \& Electronic Engineering & $1.9 \%$ & 3 & 6.0 \\
\hline & Mechanical Engineering & $1.7 \%$ & 2 & 7.8 \\
\hline & Chemical Engineering & $2.4 \%$ & 2 & 6.0 \\
\hline & Materials Engineering & $1.6 \%$ & 2 & 6.0 \\
\hline & Medical Engineering & $1.6 \%$ & 2 & 6.2 \\
\hline & Environmental Engineering & $2.2 \%$ & 2 & 6.9 \\
\hline & Environmental Biotechnology & $1.5 \%$ & 3 & 7.1 \\
\hline & Industrial Biotechnology & $1.5 \%$ & 6 & 6.2 \\
\hline & Nano-Technology & $0.0 \%$ & 2 & 4.2 \\
\hline & Other Engineering \& Technologies & $2.0 \%$ & 3 & 6.7 \\
\hline & Sub Total & $1.9 \%$ & 2 & 6.5 \\
\hline Total & Citation Peak-Time Total & $1.6 \%$ & 3 & 7.3 \\
\hline
\end{tabular}

This research also calculated the immediacy citation rate, citation peak-time, and citation half-time for the top $40 \mathrm{SCIE}$ journals in natural science and engineering. In natural science, Applied Physics Letters (14,543 citations) was highly cited by Korean journals followed by Science $(14,405$ citations); the immediacy citation rates for these journals were 0.6 percent and 0.4 percent, the citation peak-times were 5 and 9, and citation half-time was 7.2 and 10.4, respectively. In engineering, Applied and Environmental Microbiology (7,529 citations) was highly cited by Korean journals followed by Food Chemistry (5,942 citations). The immediacy citation rates for these journals were 0.5 percent and 3.3 percent, the citation peak-times were 9 and 3, and the citation half-time was 10.7 and 4.4, respectively.

\section{Co-Citation Network Analysis of SCIE Journals based on KSCD}

We conducted co-citation network analysis and social network analysis for the cited 7,605 SCIE journals that appeared in the references of Korean natural science and engineering journals from 2009 to 2014 based on KSCD. As the first step, we created a journal co-citation network matrix based on the frequency of co-citations in 7,605 SCIE journals. To avoid any bias regarding disciplines, we used the citation numbers in each journal divided by its total number of references (i.e., SCIE journal citations) (Small and Sweeney 1985). Based on the journal co-citation network matrix, we (a) created the journal co-citation network by using Gephi and measured the basic information of the network and major centrality values; (b) created the subject co-citation matrix based on the citation frequencies of subject areas using the above method; and (c) employed VOSviewer to visualize the co-citation network of journals and subject areas, and created the co-citation maps of journals and subject areas. 
The analysis of results of the co-citation network for journals and subject areas are presented in this section. We analyzed the co-citation matrix of the 7,605 SCIE journals which were cited more than once in KSCD by using Gephi. There are 7,591 nodes, excluding the journals which have only self-citations, and there are 1,130,542 total edges of those nodes with an average difference of 297.9. In addition, the network density is 0.039, which measures the level of connections among nodes in a network. We calculated the centrality index for each journal based on the co-citation network of journals, and we identified top 20 SCIE journals in natural science and engineering based on the weighted degree. Table 5 shows the averages of centrality indexes of SCIE journals in subject areas in natural science and engineering.

Table 5: Analysis Results of Co-Citation Network Centrality of Natural Science and Engineering SCIE Journals (OECD Subject Category Centrality Indexes)

\begin{tabular}{|c|c|c|c|c|c|c|}
\hline $\begin{array}{c}\text { Main } \\
\text { Category }\end{array}$ & Mid Category & $\begin{array}{c}\text { Degree } \\
\text { Sum }\end{array}$ & $\begin{array}{c}\text { Degree } \\
\text { Average }\end{array}$ & $\begin{array}{l}\text { Weighted } \\
\text { Degree } \\
\text { Average }\end{array}$ & $\begin{array}{l}\text { Closeness } \\
\text { centrality } \\
\text { Average }\end{array}$ & $\begin{array}{c}\text { Betweenness } \\
\text { centrality } \\
\text { Average }\end{array}$ \\
\hline \multirow{7}{*}{ 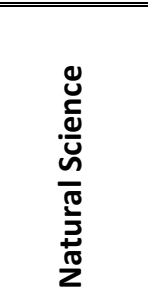 } & Mathematics & 73,816 & 132.5 & 80.7 & 0.42995 & 0.00012 \\
\hline & Computer \& Info. Sciences & 38,513 & 147.0 & 88.3 & 0.44313 & 0.00011 \\
\hline & Physical Sciences \& Astronomy & 74,691 & 270.6 & 311.3 & 0.46576 & 0.00018 \\
\hline & Chemical Sciences & 163,106 & 458.2 & 319.5 & 0.48463 & 0.00019 \\
\hline & Earth \& Related Environ. Science & 112,412 & 238.2 & 155.3 & 0.46164 & 0.00026 \\
\hline & Biological Sciences & 441,604 & 415.0 & 157.4 & 0.47765 & 0.00015 \\
\hline & Other Natural Sciences & 23,934 & 569.9 & 636.9 & 0.47439 & 0.00369 \\
\hline \multirow{14}{*}{ 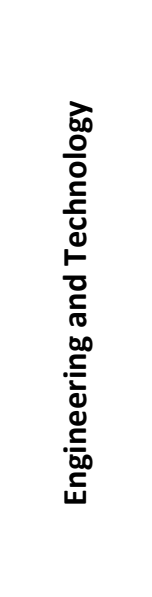 } & Sub Total & 928,076 & 306.4 & 176.7 & 0.46309 & 0.00021 \\
\hline & Civil Engineering & 28,961 & 235.5 & 283.0 & 0.45575 & 0.00014 \\
\hline & Electrical \& Electronic Eng. & 53,670 & 195.9 & 232.6 & 0.45359 & 0.00012 \\
\hline & Mechanical Engineering & 61,903 & 285.3 & 234.0 & 0.46692 & 0.00013 \\
\hline & Chemical Engineering & 35,348 & 431.1 & 364.4 & 0.48180 & 0.00019 \\
\hline & Materials Engineering & 83,895 & 319.0 & 330.8 & 0.46724 & 0.00012 \\
\hline & Medical Engineering & 26,129 & 368.0 & 86.3 & 0.48098 & 0.00017 \\
\hline & Environmental Engineering & 23,098 & 197.4 & 154.1 & 0.45192 & 0.00007 \\
\hline & Environmental Biotechnology & 62,776 & 627.8 & 294.2 & 0.49665 & 0.00028 \\
\hline & Industrial Biotechnology & 4,115 & 823.0 & 774.8 & 0.50915 & 0.00101 \\
\hline & Nano-Technology & 256 & 128.0 & 12.2 & 0.46845 & 0.00001 \\
\hline & Other Eng. and Technologies & 100,602 & 374.0 & 235.2 & 0.47104 & 0.00018 \\
\hline & Sub Total & 480,753 & 315.7 & 254.1 & 0.46680 & 0.00015 \\
\hline & Total & $1,408,829$ & 297.9 & 149.8 & 0.46385 & 0.00016 \\
\hline
\end{tabular}

In the natural science, Biological Sciences has the highest sum of degrees, and Other Natural Sciences has the highest average of weighted degree (i.e., degree centrality). Chemical Sciences has the highest average of closeness centrality, and Other Natural Sciences has the highest average of betweenness centrality. In engineering, Other Engineering and Technologies has the highest sum of degrees, and Industrial Biotechnology has the highest averages of weighted degree (i.e., degree centrality), closeness centrality, and betweenness centrality. The engineering journals have higher centrality indexes, except with betweenness centrality, as compared to natural science SCIE journals.

In the subject area co-citation network, there are 29 subject areas for the 7,591 nodes of SCIE journals, and 399 edges for those subject areas. The total number of the degree of nodes (i.e., the number of nodes connected to other nodes) is 798 and the average degree 
is 27.5. Additionally, the network density (ranging from 0 to 1 ), which represents the connectivity of nodes in a network, is 0.983 . Biological sciences $(82,430.1)$ has the highest network weighted degree in natural science, followed by Chemical Sciences $(66,141.5)$ and Physical Sciences and Astronomy $(45,623.7)$. In engineering, material engineering $(54,417.1)$ has the highest network weighted degree followed by Mechanical Engineering $(30,113.01)$.

Figure 2 shows the co-citation network among subject areas, and it suggests that Chemical Sciences, Materials Engineering, Biological Sciences, Clinical Medicine, Chemical Sciences, Physical Sciences and Astronomy, Biological Sciences, and Basic Medical Research have the strong co-citation relationships among subject areas.

Figure 3 provides a visualization of the co-citation network of SCIE journals by creating a network map using VOSviewer. This figure shows the co-citation intensity of major journals through this network map. The network clustering (color) and the sizes of journals are determined by Linlog/modularity analysis method of VOSviewer.

Figure 2: Co-Citation Map of OECD Subject Categories (29 sub categories) Network Visualization*

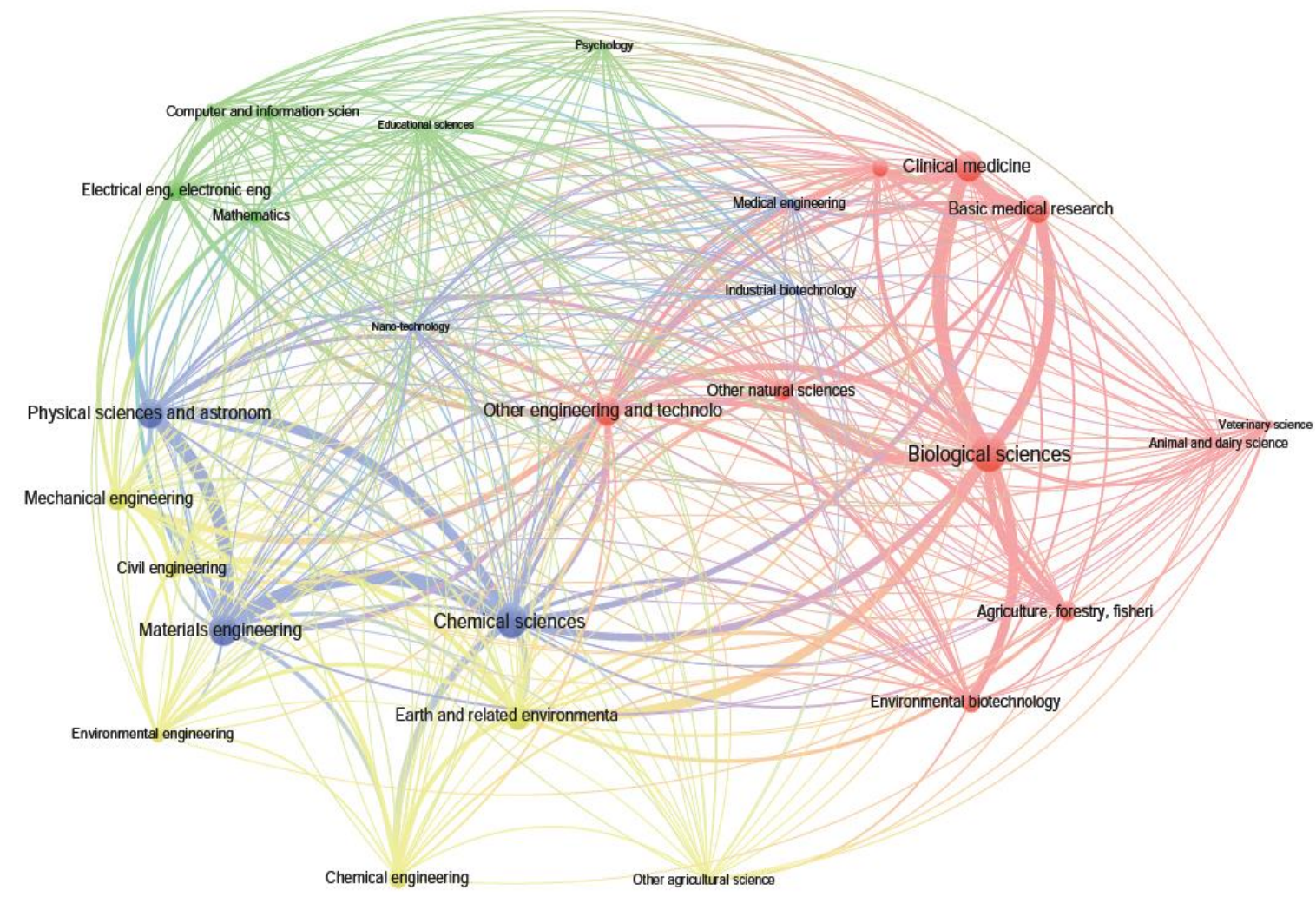

*Network Visualization Using VOSviewer (SCIE journals, OECD FOS subject area mapping, co-citation matrix was normalized by VOSviewer's association method) 
Figure 3: Co-citation Map of SCIE Journals Network Visualization*

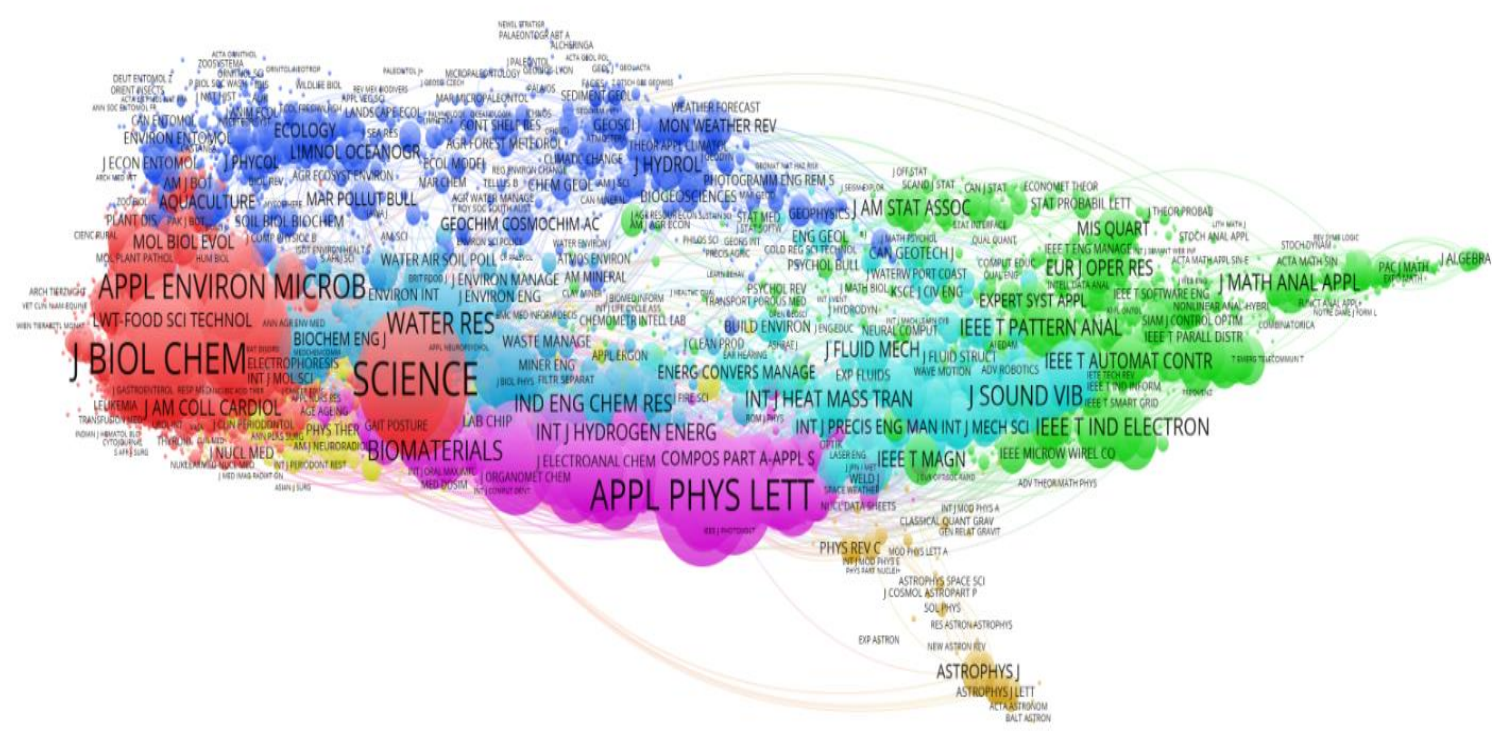

*Network map was created by using VOSviewer, Co-citation matrix was normalized by VOSviewer's Linlog/modularity method

\section{Ranking Change Experiment of SCIE Journals based on KSCD}

We investigated the effect of the SCIE journals' IF (2 years) adjusted by the Korean natural science and engineering journals on the ranking of SCIE journals compared to the existing IF ranking. We used the $2014 \mathrm{JCR}$ for SCIE that was published in 2015. The ranges of experiment data include the 2014 citation records of SCIE journals in the KSCD natural science and engineering areas (presented in Table 1 and 2), and based on this data range, we only used 2012-2013 citation records for recalculating the IF ( 2 years).

Since JCR already included the citation records of 93 Korean SCIE journals in natural science and engineering, we excluded them in this data analysis. Therefore, the final experiment target includes the 36,994 citation records of Korean natural science and engineering journals for 5,454 SCIE journals mapped in 8,618 SCIE journals in 2014 JCR. There was a total of 3,164 SCIE journals that were excluded from this data analysis because we only focused on the Korean journals in natural science and engineering of KSCD.

For the experiment procedure, first, we added the citation records of KSCD journals into the citation frequencies of 2014 JCR journals from 2009 to 2013 for each year. Second, we calculated the IF ( 2 years) based on the aggregated citation frequencies for each JCR journal. Third, we compared the IF ( 2 years) of 2014 JCR and the aggregated IF ( 2 years) for each JCR journal. Fourth, we analyzed the updated data for each journal by OCED and WOS subject category. We also analyzed the relationship between the existing index and the aggregated index for 'Electrical \& Electronic Engineering', which was used in the specific experiment of the prior JCR ranking change experiment based on KSCD (Lee et al. 2012).

We then calculated the difference of ranking change for each journal based on the IF ( 2 years) of $2014 \mathrm{JCR}$ and the percent rank value of the newly aggregated IF ( 2 years). Table 6 presents the top $20 \mathrm{SCIE}$ journals that have the largest differences. Those top 20 journals are all from the SCIE journals published in the Republic of Korea (c.f., 45 Korean journals out of $50 \mathrm{SCIE}$ 
journals, and 56 Korean journals out of $100 \mathrm{SCIE}$ journals). This result indicates that citation records from Korean natural science and engineering journals significantly influence the rank change of the Korean SCIE journals rather than other SCIE journals from other nations. This result suggests that as more Korean natural science and engineering journals move into SCIE journals, the influence of Korean journals would increase their citation impacts of the existing and newly added Korean SCIE journals.

Table 6: The List of Top 20 Journals for Ranking Change Experiment

\begin{tabular}{|c|c|c|c|c|c|c|c|}
\hline 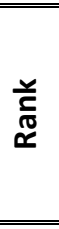 & $\begin{array}{c}\text { WOS } \\
\text { Subject Category }\end{array}$ & WOS Journal Title & $\begin{array}{r}\text { (A) } \\
\text { JCR } \\
2014 \\
\mathrm{IF} \\
\text { (2year) } \\
\end{array}$ & $\begin{array}{r}\text { (B) } \\
\text { Percent } \\
\text { Rank of } \\
\text { (A) }\end{array}$ & $\begin{array}{r}(\mathrm{C}) \\
\text { Aggreg } \\
\text { ated } \\
\mathrm{IF} \\
\text { (2year) } \\
\end{array}$ & $\begin{array}{r}\text { (D) } \\
\text { Percent } \\
\text { Rank } \\
\text { of (C) }\end{array}$ & $\begin{array}{r}\text { Rank } \\
\text { Change } \\
\text { (D-B) }\end{array}$ \\
\hline 1 & Optics & $\begin{array}{l}\text { Journal of the Optical } \\
\text { Society of Korea }\end{array}$ & 1.179 & $30.3 \%$ & 1.833 & $50.0 \%$ & $19.7 \%$ \\
\hline 2 & $\begin{array}{l}\text { Construction \& Building } \\
\text { Tech. }\end{array}$ & $\begin{array}{l}\text { Steel \& Composite } \\
\text { Structures }\end{array}$ & 0.964 & $23.5 \%$ & 1.604 & $43.2 \%$ & $19.7 \%$ \\
\hline 3 & Mechanical Engineering & $\begin{array}{l}\text { Intl' Journal of Precision } \\
\text { Eng. \& Manufacturing }\end{array}$ & 1.205 & $31.1 \%$ & 1.81 & $49.3 \%$ & $18.2 \%$ \\
\hline 4 & $\begin{array}{l}\text { Material Science, } \\
\text { Multidisciplinary }\end{array}$ & Electronic Materials Letters & 1.98 & $53.9 \%$ & 2.81 & $71.9 \%$ & $18.0 \%$ \\
\hline 5 & Civil Engineering & $\begin{array}{l}\text { Structural Engineering \& } \\
\text { Mechanics }\end{array}$ & 0.927 & $21.7 \%$ & 1.464 & $38.9 \%$ & $17.2 \%$ \\
\hline 6 & Civil Engineering & $\begin{array}{l}\text { Earthquakes and } \\
\text { Structures }\end{array}$ & 0.693 & $13.6 \%$ & 1.219 & $30.8 \%$ & $17.2 \%$ \\
\hline 7 & Civil Engineering & $\begin{array}{l}\text { Geomechanics and } \\
\text { Engineering }\end{array}$ & 0.604 & $10.4 \%$ & 1.057 & $26.0 \%$ & $15.6 \%$ \\
\hline 8 & $\begin{array}{l}\text { Construction \& Building } \\
\text { Tech. }\end{array}$ & Computers and Concrete & 0.869 & $19.6 \%$ & 1.34 & $34.9 \%$ & $15.3 \%$ \\
\hline 9 & $\begin{array}{l}\text { Meteorology \& } \\
\text { Atmospheric Sci. }\end{array}$ & $\begin{array}{l}\text { Asia-Pacific Journal of } \\
\text { Atmospheric Sciences }\end{array}$ & 1.347 & $35.6 \%$ & 1.851 & $50.5 \%$ & $14.9 \%$ \\
\hline 10 & Mechanical Engineering & $\begin{array}{l}\text { International Journal of } \\
\text { Automotive Technology }\end{array}$ & 0.969 & $23.7 \%$ & 1.45 & $38.5 \%$ & $14.8 \%$ \\
\hline 11 & $\begin{array}{l}\text { Electrical \& Electronic } \\
\text { Eng. }\end{array}$ & $\begin{array}{l}\text { Journal of Power } \\
\text { Electronics }\end{array}$ & 0.777 & $16.3 \%$ & 1.214 & $30.6 \%$ & $14.3 \%$ \\
\hline 12 & $\begin{array}{l}\text { Metallurgy \& } \\
\text { Metallurgical Eng }\end{array}$ & $\begin{array}{l}\text { Korean Journal of Metals } \\
\text { and Materials }\end{array}$ & 1.405 & $37.4 \%$ & 1.883 & $51.2 \%$ & $13.8 \%$ \\
\hline 13 & $\begin{array}{l}\text { Chemistry, } \\
\text { Multidisciplinary }\end{array}$ & Carbon Letters & 1.625 & $44.4 \%$ & 2.138 & $57.5 \%$ & $13.1 \%$ \\
\hline 14 & Mechanical Engineering & $\begin{array}{l}\text { Journal of Mechanical } \\
\text { Science \& Technology }\end{array}$ & 0.838 & $8.7 \%$ & 1.232 & $31.4 \%$ & $12.7 \%$ \\
\hline 15 & Civil Engineering & $\begin{array}{l}\text { Smart Structures and } \\
\text { Systems }\end{array}$ & 1.368 & $36.3 \%$ & 1.789 & $48.8 \%$ & $12.5 \%$ \\
\hline 16 & $\begin{array}{l}\text { Metallurgy \& } \\
\text { Metallurgical Eng }\end{array}$ & $\begin{array}{l}\text { Metals and Materials } \\
\text { International }\end{array}$ & 1.579 & $43.1 \%$ & 2.061 & $55.5 \%$ & $12.4 \%$ \\
\hline 17 & $\begin{array}{l}\text { Polymer } \\
\text { Science }\end{array}$ & Polymer-Korea & 0.528 & $8.1 \%$ & 0.901 & $20.2 \%$ & $12.1 \%$ \\
\hline 18 & $\begin{array}{l}\text { Automation \& Control } \\
\text { Systems }\end{array}$ & $\begin{array}{l}\text { Intl' Journal of Control } \\
\text { Automation \& Systems }\end{array}$ & 0.954 & $22.9 \%$ & 1.321 & $34.3 \%$ & $11.4 \%$ \\
\hline 19 & $\begin{array}{l}\text { Biochemical Research } \\
\text { Method }\end{array}$ & Biochip Journal & 1.09 & $27.5 \%$ & 1.43 & $37.6 \%$ & $10.1 \%$ \\
\hline 20 & Telecommunications & $\begin{array}{l}\text { ETRI } \\
\text { Journal }\end{array}$ & 0.771 & $16.1 \%$ & 1.058 & $26.0 \%$ & $9.9 \%$ \\
\hline
\end{tabular}


Table 7 presents the comparison between the 2014 IF ( 2 years) of the journals and the percentage rank of aggregated index by subject areas. The significant ranking increase was observed in engineering followed by natural science, agricultural, water, and ocean sciences, and medical and pharmaceutical sciences by reviewing the main categories that have more than 100 journals. By reviewing the mid-category, in natural science, 'Computer and Information Sciences' has the highest-ranking change rate (42.6\%), and in engineering, there are a number of mid-categories which have more than 50 percent of ranking change, including: 'Nano-Technology' (100\%), 'Civil Engineering' (60.7\%), 'Electrical Engineering, Electronic Engineering' (59.9\%), 'Environmental Engineering' (53.1\%), 'Chemical Engineering' (52.9\%), 'Mechanical Engineering' (50.8\%). In conclusion, this results of this research indicate that citation records by Korean natural science and engineering journals can change the ranking of $\mathrm{SCIE}$ journals in the entire engineering disciplines, rather than in the natural science disciplines.

Table 7: Ranking Change Result by Subject Areas (IF based on KSCD VS. Existing 2014 JCR IF)

\begin{tabular}{|c|c|c|c|c|c|}
\hline Main Category & Mid-Category & $\begin{array}{r}\text { No. of } \\
\text { journals }\end{array}$ & $\begin{array}{r}\text { IF } 2 \text { year } \\
\mathbf{N}>0\end{array}$ & $\begin{array}{r}\text { IF } 2 \text { year } \\
\mathrm{N}<=0\end{array}$ & $\begin{array}{l}\text { IF } 2 \text { year } \\
\text { N>0 rate }\end{array}$ \\
\hline \multirow{8}{*}{$\begin{array}{l}\text { National } \\
\text { Science }\end{array}$} & Computer and Information Sciences & 202 & 86 & 116 & $42.6 \%$ \\
\hline & Earth \& Related Environ. Sciences & 338 & 72 & 266 & $21.3 \%$ \\
\hline & Mathematics & 346 & 67 & 279 & $19.4 \%$ \\
\hline & Physical Sciences and Astronomy & 218 & 39 & 179 & $17.9 \%$ \\
\hline & Chemical Sciences & 285 & 49 & 236 & $17.2 \%$ \\
\hline & Biological Sciences & 780 & 129 & 651 & $16.5 \%$ \\
\hline & Other Natural Sciences & 24 & 2 & 22 & $8.3 \%$ \\
\hline & Sub Total & 2,193 & 444 & 1,749 & $20.2 \%$ \\
\hline \multirow{11}{*}{$\begin{array}{l}\text { Engineering } \\
\text { and } \\
\text { Technology }\end{array}$} & Nano-Technology & 1 & 1 & - & $100.0 \%$ \\
\hline & Civil Engineering & 107 & 65 & 42 & $60.7 \%$ \\
\hline & Electrical \& Electronic Engineering & 242 & 145 & 97 & $59.9 \%$ \\
\hline & Environmental Engineering & 98 & 52 & 46 & $53.1 \%$ \\
\hline & Chemical Engineering & 70 & 37 & 33 & $52.9 \%$ \\
\hline & Mechanical Engineering & 189 & 96 & 93 & $50.8 \%$ \\
\hline & Other Engineering \& Technologies & 217 & 88 & 129 & $40.6 \%$ \\
\hline & Materials Engineering & 222 & 79 & 143 & $35.6 \%$ \\
\hline & Environmental Biotechnology & 82 & 29 & 53 & $35.4 \%$ \\
\hline & Medical Engineering & 58 & 14 & 44 & $24.1 \%$ \\
\hline & Industrial Biotechnology & 5 & 1 & 4 & $20.0 \%$ \\
\hline \multirow{5}{*}{$\begin{array}{l}\text { Medical and } \\
\text { Health } \\
\text { Sciences }\end{array}$} & Sub Total & 1,291 & 607 & 684 & $47.0 \%$ \\
\hline & Basic Medical Research & 402 & 33 & 369 & $8.2 \%$ \\
\hline & Health Sciences & 321 & 25 & 296 & $7.8 \%$ \\
\hline & Clinical Medicine & 912 & 46 & 866 & $5.0 \%$ \\
\hline & Sub Total & 1,635 & 104 & 1,531 & $6.4 \%$ \\
\hline \multirow{5}{*}{$\begin{array}{l}\text { Agricultural } \\
\text { Sciences }\end{array}$} & Other Agricultural Science & 7 & 2 & 5 & $28.6 \%$ \\
\hline & Animal and Dairy Science & 32 & 7 & 25 & $21.9 \%$ \\
\hline & Agriculture, Forestry, Fisheries & 145 & 23 & 122 & $15.9 \%$ \\
\hline & Veterinary Science & 51 & 5 & 46 & $9.8 \%$ \\
\hline & Sub Total & 235 & 37 & 198 & $15.7 \%$ \\
\hline \multirow{4}{*}{ Social Sciences } & Economics and Business & 33 & 11 & 22 & $33.3 \%$ \\
\hline & Educational Sciences & 20 & 1 & 19 & $5.0 \%$ \\
\hline & Psychology & 41 & 1 & 40 & $2.4 \%$ \\
\hline & Sub Total & 94 & 13 & 81 & $13.8 \%$ \\
\hline \multirow[t]{2}{*}{ Humanities } & History and Archaeology & 6 & 1 & 5 & $16.7 \%$ \\
\hline & Grand Total & 5,454 & 1,206 & 4248 & $22.1 \%$ \\
\hline
\end{tabular}


Finally, we analyzed the correlation in the specific area of 'Electrical \& Electronic Engineering', in which the prior study on JCR ranking change experiment was conducted by reflecting KSCD (Lee at al. 2012). The Pearson correlation coefficients show the significant correlations in the overall ranges except for two of these ranges that were less than 0.6; the correlation coefficient for the range of 91 to 100 was lower than 0.5 , which shows a low relationship (Table 8). Therefore, this research confirmed that the citations by the Korean natural science and engineering journals in KSCD can significantly influence the ranking changes in the various subject areas of JCR.

Table 8: Pearson Correlation Coefficients of Journal Ranking Changes based on IF (2 years) (Electrical \& Electronic Engineering)

\begin{tabular}{cc}
\hline $\begin{array}{c}\text { Ranking Range } \\
\text { (KSCD+JCR 2014) }\end{array}$ & $\begin{array}{c}\text { Results of Correlation Analysis } \\
\text { (comparison: JCR 2014) }\end{array}$ \\
\hline $1-10$ & 1.0000 \\
$11-20$ & 0.9758 \\
$21-30$ & 0.9030 \\
$31-40$ & 0.9879 \\
$41-50$ & 0.9766 \\
$51-60$ & 0.9861 \\
$61-70$ & 0.9649 \\
$71-80$ & 0.5430 \\
$81-90$ & 0.9152 \\
$91-100$ & 0.3435 \\
$101-110$ & 0.8630 \\
$111-120$ & 0.9028 \\
$121-130$ & 0.9656 \\
$131-140$ & 0.9850 \\
\hline \hline
\end{tabular}

\section{DISCUSSION}

This research analyzed the citation impact of Korean natural science and engineering journals, which have the highest citations toward SCIE journals. The scope of the experiment includes the SCIE citation data by the Korean journals in natural science and engineering from 2009 to 2014, and this research conducted citation analysis and co-citation network analysis. We also conducted the ranking change experiment in major citation indexes by applying citation data from Korean journals into 2014 JCR.

First, this research measured the citation age such as citation status, citation peak-time, and citation half-time by journal and subject area. The results indicate that 311 journals have more than 1,000 citations, accounting for more than 50 percent of total citations among a total of 7,603 SCIE journals. In addition, natural science have the highest number of citations $(3,038$ journals, $45.8 \%$ of share rate) followed by engineering $(1,525$ journals, $35.5 \%$ of share rate). The natural science has a higher number of journals cited and number of citations than engineering, however, engineering has more citation rates by number of journals. According 
to the mid-subject category in natural science, Biological Sciences (13.3\%) and Chemical Sciences $(9.5 \%)$ have high share rates by number of citations compared to the entire citations. In engineering, Materials Engineering (7.5\%) and Electrical \& Electronic Engineering (6.5\%) have a high citation share rate. Based on the results of citation age analysis, engineering journals have high immediacy citation rate (natural science: $1.4 \%$ vs engineering: 1.9\%), citation peak-time (natural science: 3 years vs engineering: 2 years), and citation half-time (natural science: 8.1 years vs engineering: 6.5 years) compared to the natural science journals. In both engineering and natural science, the immediacy citation rate was 1.6 percent; the citation peak-time was 3 years, and the citation half-time was 7.3 years, which is relatively lower than Choi and colleagues' recent study (i.e., 9 years) with international engineering journals (Choi et al. 2013). Since the engineering journals have more application research, their SCIE journal articles were consumed and in decline quickly compared to natural science, which pursue more fundamental science research.

Second, this research visualized the co-citation network of SCIE journals and subject areas based on the citations by Korean natural science and engineering journals and measured the network centrality indexes by subject area and journal. In natural science, 'Other Natural Sciences' has the highest averages of weighted degree (i.e., local degree centrality) and betweenness centrality, and 'Chemical Sciences' has the highest average of closeness centrality. In engineering, 'Other Engineering and Technologies' has the high sum of degree, and 'Industrial Biotechnology' has the highest averages of weighted degree (i.e., local degree centrality), closeness centrality, and betweenness centrality. The engineering journals have higher centrality indexes except betweenness centrality as compared to natural science journals.

Third, we calculated the difference of ranking change for each journal based on the percent rank of aggregated IF ( 2 years) by reflecting 5-year journal IF of 2014 JCR and the citation records of Korean natural science and engineering journals in KSCD. We found that the Korean SCIE journals are included within the top 20 rank ( 45 Korean SCIE journals in the top 50 , and 56 Korean SCIE journals in the top 100), which shows that the Korean journals significantly influence the ranking change of Korean SCIE journals rather than other SCIE journals from other nations. This result confirmed what Miguel-Dasit et al. (2005) found about Spanish journals' positive impact on the existing JCR ranking especially focusing on European journals. Additionally, by comparing the 2014 JCR IF ( 2 years) of journals and the percentage index rank of the aggregated index by subject areas, we found that the major subject areas for the ranking changes (i.e., increase of ranking) of journals include: engineering followed by natural science, agricultural, water, and ocean sciences, and medical and pharmaceutical sciences by the main categories. According to the mid-category, in natural science, 'Computer and Information Sciences' has the highest-ranking change ratio (42.6\%). In engineering, the mid-categories that have more than 50 percent of ranking change ratio includes: 'Nano-Technology' (100\%), 'Civil Engineering' (60.7\%), 'Electrical Engineering, Electronic Engineering' (59.9\%), 'Environmental Engineering' (53.1\%), 'Chemical Engineering' (52.9\%), and 'Mechanical Engineering' (50.8\%). We also analyzed the correlation in the specific area of 'Engineering, Electrical \& Electronic', in which the prior study on JCR ranking change experiment was conducted by reflecting KSCD. The Pearson correlation coefficients show the significant correlations in the overall ranges, except two ranges which have less than 0.6 ; the correlation coefficient for the range of 91 to 100 is lower than 0.5 , which shows a very low correlation. This finding supports what Lee et al. (2012) found from their JCR ranking change experiment. Therefore, this research confirmed that the citations by the Korean natural science and engineering journals in KSCD can significantly influence the ranking changes in the various subject areas of JCR. 
This research has diverse practical implications. First, the results of this research can be used for Korean academic libraries to subscribe appropriate academic journals for their researchers as a guideline. Korean academic libraries mostly utilize JCR as a guideline for their journal subscriptions; however, this research can provide a new guideline for Korean academic libraries to evaluate a number of $\mathrm{SCl}$ journals for subscription. Second, the results of this research can be also used for scholarly search services in Korea (e.g., Korean National Digital Science Library and scholarly search in Naver.com) to recommend highly cited SCIE academic journals in Korea. Especially, those scholarly search services in Korea can prioritize their search results based on the updated journal rankings from this study. Third, the research method and procedure in this research can be applied for other Asian countries to develop their own JCR rankings based on their researchers' usages and needs of academic journals. This will eventually help domestic academic libraries in Asian countries to better identify suitable academic journals and provide better scholarly services in their countries.

\section{CONCLUSION}

This research showed that the Korean natural science and engineering journals have significant citation impacts on SCIE journals in terms of JCR ranking changes. First, we found that the articles in engineering are rapidly used up than the articles in natural science by reviewing the cited numbers and citation age through the citation analysis of the cited SCIE journals. Second, this research showed that the Korean journal citations significantly affect the existing journal IF ( 2 years) and the JCR journal rankings in engineering and natural science journals. Third, this research suggested that the impact of Korean journals on SCIE journals can be utilized for the evaluation of existing journals in a national perspective. Finally, this research recommended that Asian countries can consider to develop their own revised JCR rankings to better evaluate the existing JCR rankings by reflecting the citations of their countries' academic journals into JCR.

In terms of future research, first, it is necessary to analyze the citation impact of the entire research areas of science and technology by including health sciences in Korea. Also, future research can extend the current research to the citation impact of Korean social science journals toward $\mathrm{SSCl}$ journals. Second, future research can examine the citation impact of domestic journals toward academic conference proceedings, especially in computer sciences, which have high citation rates toward academic conference proceedings. Third, future research can be extended to investigate the authors and research institutions of journal articles in terms of their citation status and author co-citation network. Additionally, in the technical perspective, future research can consider developing a scholarly information database for identifying authors, articles, and their references more rapidly and precisely. The scholarly information database can be utilized to monitor the citation status of domestic journals toward SCIE and SSCl journals and provide better scholarly services for domestic researchers in Asian countries.

\section{ACKNOWLEDGEMENT}

This research received no specific grant from any funding agency in the public, commercial, or not-for profit sectors. 


\section{REFERENCES}

Aleixandre-Benavent, R., Zurián, J.C.V, Miguel-Dasit, A., Arroyo, A. and Gómez, M. 2007. Hypothetical influence of non-indexed Spanish medical journals on the impact factor of the Journal Citation Reports-indexed journals. Scientometrics, Vol. 70, no. 1: 53-66.

Bastian, M., Heymann, S. and Jacomy, M. 2009. Gephi: an open source software for exploring and manipulating networks. ICWSM, Vol. 8: 361-362.

Boyack, K. W., Klavans, R. and Börner, K. 2005. Mapping the backbone of science. Scientometrics, Vol.64, no. 3: 351-374.

Choi, H., Kim, B., Jung, Y. and Choi, S. 2013. Korean scholarly information analysis based on Korea Science Citation Database (KSCD). Collnet Journal of Scientometrics and Information Management, Vol.7, no. 1: 1-33.

Dolfsma, W. and Leydesdorff, L. 2008. Journals as constituents of scientific discourse: economic heterodoxy. On the Horizon, Vol. 16, no. 4: 214-225.

Freeman, L.C. 1978. Centrality in social networks conceptual clarification. Social networks, Vol. 1, no. 3: 215-239.

Garfield, E. 2006. Citation indexes for science. A new dimension in documentation through association of ideas. International Journal of Epidemiology, Vol. 35, no. 5: 1123-1127.

Jin, B. and Wang, B. 1999. Chinese Science Citation Database: its construction and application. Scientometrics, Vol. 45, no. 2: 325-332.

Jo, S.R. and Lee, J.Y. 2012. Journal co-citation analysis for library services in pharmaceutics. Journal of Information Management, Vol. 43, no. 1: 159-185.

Kang, M.Y. and Kim, B. 2015. A survey of science-technology Korean journal. Daejeon: KISTI.

Kessler, M.M. 1963. Bibliographic coupling between scientific papers. Journal of the Association for Information Science and Technology, Vol. 14, no. 1: 10-25.

Kim, B., So, M. and Choi, S.H. 2014. Korea's STEM research analysis based on publications in the Web of Science, 1968-2012. Journal of Information Science Theory and Practice, Vol.2, no. 1: 35-47.

$\mathrm{KSCl}$. Korea Science Citation Index Service. accessed March 20. Available at: http://ksci.kisti.re.kr.

Lee, J.W., Yang, K.D., Kim, B.K. and You, B.J. 2012. Analysis of Korea science citation database's effect on JCR. Journal of Information Management, Vol. 43, no. 3: 23-41.

Lee, K.J. and Yoon, S.K. 1996. A study on journal citation analysis. Korean Republic Administration Review, Vol. 30, no. 2: 97-112.

Leydesdorff, L. and Zhou, P. 2005. Are the contributions of China and Korea upsetting the world system of science? Scientometrics, Vol. 63, no. 3: 617-630.

Liu, G.Y., Hu, J.M. and Wang, H.L. 2012. A co-word analysis of digital library field in China. Scientometrics, Vol. 91, no. 1: 203-217.

Marshakova, I.V. 1973. System of document connections based on references. NauchnoTekhnicheskaya Informatsiya Seriya 2-Informatsionnye Protsessy I Sistemy, no. 6: 3-8.

McCain, K. W. 1991. Mapping economics through the journal literature: An experiment in journal cocitation analysis. Journal of the American Society for Information Science, Vol. 42, no.4: 290.

Meho, L. I. and Yang, K. 2007. Impact of data sources on citation counts and rankings of LIS faculty: Web of Science versus Scopus and Google Scholar. Journal of the American Society for Information Science and Technology, Vol. 58, no. 13: 2105-2125.

Miguel-Dasit, A., Aleixandre, R., Valderrama, J. C., Martí-Bonmatí, L. and Sanfeliu, P. 2005. Hypothetical influence of non-indexed Spanish journals on the impact factor of radiological journals. European Journal of Radiology, Vol. 54, no. 3: 321-326. 
Zainab, A.N., Sanni, S.A., Edzan, NN. and Koh, A.P. 2012. Auditing scholarly journals published in Malaysia and assessing their visibility. Malaysian Journal of Library \& Information Science Vol. 17, no. 1: 65-92.

OECD. 2017. Main Science and Technology Indicators. accessed March 28. Available at : http://www.oecd.org/science/msti.htm.

Small, H. 1973. Co-citation in the scientific literature: A new measure of the relationship between two documents. Journal of the Association for Information Science and Technology, Vol. 24, no. 4: 265-269.

Small, H. and Garfield, E. 1985. The geography of science: disciplinary and national mappings. Information Scientist, Vol. 11, no. 4: 147-159.

Small, H. and Sweeney, E. 1985. Clustering the science citation index ${ }^{\circledR}$ using co-citations: I. A comparison of methods. Scientometrics, Vol.7, no.3-6:391-409.

So, M. 2015. SCI Analysis Research, ICT and Future Planning. Seoul: Ministry of Science.

Sombatsompop, N., Chancheewa, S., Markpin, T., Premkamolnetr, N., Ittiritmeechai, S., Wongkaew, C., Yochai, W. and Ratchatahirun, P. 2012. Thai -Journal Citation Index (TCI) centre: 10 years of experiences, lessons learned, and ongoing dev. Malaysian Journal of Library \& Information Science Vol. 17, no. 3: 17-33.

Van Eck, N. and Waltman, L. 2010. Software survey: VOSviewer, a computer program for bibliometric mapping. Scientometrics, Vol. 84, no. 2: 523-538.

White, H. D. and Griffith, B. C. 1981. Author cocitation: A literature measure of intellectual structure. Journal of the Association for Information Science and Technology, Vol. 32, no. 3: 163-171.

Wu, J., Xiao, H., Sheng, S., Zhang, Y.n, Sun X. and Zhang, Y. 2015. The Research Purpose, Methods and Results of the Annual Report for International Citations of China's Academic Journals'. International Conference of the International Society for Scientometrics and Informetrics (ISSI), Istanbul, Turkey.

Zhao, D. and Strotmann, A. 2008. Evolution of research activities and intellectual influences in information science 1996-2005: Introducing author bibliographic-coupling analysis. Journal of the American Society for Information Science and Technology, Vol. 59, no. $13: 2070-2086$. 
APPENDIX

Appendix A: List of Top 20 Journals in Natural Science and Engineering (based on the number of citation)

\begin{tabular}{|c|c|c|c|c|c|c|c|}
\hline $\begin{array}{c}\text { Main } \\
\text { Category }\end{array}$ & Mid-Category & Journal Title & $\begin{array}{c}\text { Abbreviated Journal } \\
\text { Title }\end{array}$ & $\begin{array}{l}\text { No. of } \\
\text { Citation }\end{array}$ & $\begin{array}{c}\text { Immediacy } \\
\text { Citation } \\
\text { Rate }\end{array}$ & $\begin{array}{l}\text { Citation } \\
\text { Peak-Time }\end{array}$ & $\begin{array}{l}\text { Citation } \\
\text { Half-time }\end{array}$ \\
\hline \multirow{17}{*}{$\begin{array}{l}\text { Natural } \\
\text { Science }\end{array}$} & Physical sciences and astronomy & APPLIED PHYSICS LETTERS & APPL PHYS LETT & 14,543 & $0.6 \%$ & 5 & 7.2 \\
\hline & Other natural sciences & SCIENCE & SCIENCE & 14,405 & $0.4 \%$ & 9 & 10.4 \\
\hline & $\begin{array}{l}\text { Earth \& related environmental } \\
\text { sciences }\end{array}$ & ECOLOGICAL ECONOMICS & ECOL ECON & 11,931 & $0.8 \%$ & 11 & 9.3 \\
\hline & Biological sciences & JOURNAL OF BIOLOGICAL CHEMISTRY & J BIOL CHEM & 11,801 & $0.6 \%$ & 8 & 10.9 \\
\hline & Other natural sciences & $\begin{array}{l}\text { PROCEEDINGS OF THE NATIONAL ACADEMY OF } \\
\text { SCIENCES OF THE UNITED STATES OF AMERICA }\end{array}$ & P NATL ACAD SCI USA & 11,065 & $0.7 \%$ & 5 & 10.0 \\
\hline & Physical sciences and astronomy & JOURNAL OF APPLIED PHYSICS & J APPL PHYS & 9,285 & $0.6 \%$ & 6 & 10.7 \\
\hline & Chemical sciences & JOURNAL OF THE AMERICAN CHEMICAL SOCIETY & J AM CHEM SOC & 8,894 & $0.4 \%$ & 5 & 8.9 \\
\hline & Physical sciences and astronomy & PHYSICAL REVIEW B & PHYS REV B & 8,428 & $0.6 \%$ & 5 & 10.2 \\
\hline & Physical sciences and astronomy & PHYSICAL REVIEW LETTERS & PHYS REV LETT & 7,945 & $0.6 \%$ & 6 & 10.2 \\
\hline & Chemical sciences & JOURNAL OF APPLIED POLYMER SCIENCE & J APPL POLYM SCI & 6,246 & $1.0 \%$ & 3 & 8.1 \\
\hline & $\begin{array}{l}\text { Earth and related environmental } \\
\text { sciences }\end{array}$ & ENVIRONMENTAL SCIENCE \& TECHNOLOGY & ENVIRON SCI TECHNOL & 6,034 & $0.6 \%$ & 5 & 8.3 \\
\hline & Chemical sciences & JOURNAL OF POWER SOURCES & J POWER SOURCES & 5,946 & $1.8 \%$ & 3 & 5.0 \\
\hline & $\begin{array}{l}\text { Earth and related environmental } \\
\text { sciences }\end{array}$ & WATER RESEARCH & WATER RES & 5,406 & $1.1 \%$ & 9 & 8.6 \\
\hline & Chemical sciences & POLYMER & POLYMER & 5,111 & $0.5 \%$ & 9 & 8.0 \\
\hline & Chemical sciences & MACROMOLECULES & MACROMOLECULES & 4,929 & $0.2 \%$ & 7 & 9.9 \\
\hline & Chemical sciences & ADVANCED MATERIALS & ADV MATER & 4,554 & $1.4 \%$ & 4 & 5.8 \\
\hline & Biological sciences & PLANT PHYSIOLOGY & PLANT PHYSIOL & 4,178 & $0.6 \%$ & 5 & 9.6 \\
\hline
\end{tabular}


Kim, B., Kim, Y. \& Kang, J.

\begin{tabular}{|c|c|c|c|c|c|c|c|}
\hline & Chemical sciences & JOURNAL OF PHYSICAL CHEMISTRY B & J PHYS CHEM B & 3,879 & $0.2 \%$ & 8 & 7.4 \\
\hline & Biological sciences & $\begin{array}{l}\text { BIOCHEMICAL AND BIOPHYSICAL RESEARCH } \\
\text { COMMUNICATIONS } \\
\end{array}$ & BIOCHEM BIOPH RES CO & 3,597 & $1.9 \%$ & 4 & 7.1 \\
\hline & Physical sciences and astronomy & JOURNAL OF THE KOREAN PHYSICAL SOCIETY & J KOREAN PHYS SOC & 3,538 & $4.0 \%$ & 2 & 1.8 \\
\hline \multirow{20}{*}{$\begin{array}{l}\text { Engineering } \\
\text { and } \\
\text { Technology }\end{array}$} & Environmental biotechnology & APPLIED AND ENVIRONMENTAL MICROBIOLOGY & APPL ENVIRON MICROB & 7,529 & $0.5 \%$ & 9 & 10.7 \\
\hline & $\begin{array}{l}\text { Other engineering and } \\
\text { technologies }\end{array}$ & FOOD CHEMISTRY & FOOD CHEM & 5,942 & $3.3 \%$ & 3 & 4.4 \\
\hline & Materials engineering & THIN SOLID FILMS & THIN SOLID FILMS & 5,854 & $1.0 \%$ & 4 & 6.7 \\
\hline & Civil engineering & JOURNAL OF HAZARDOUS MATERIALS & J HAZARD MATER & 5,274 & $2.3 \%$ & 4 & 3.8 \\
\hline & Mechanical engineering & JOURNAL OF SOUND AND VIBRATION & J SOUND VIB & 5,200 & $0.8 \%$ & 5 & 9.1 \\
\hline & Materials engineering & $\begin{array}{l}\text { MATERIALS SCIENCE AND ENGINEERING A- } \\
\text { STRUCTURAL MATERIALS PROPERTIES } \\
\text { MICROSTRUCTURE AND PROCESSING }\end{array}$ & MAT SCI ENG A-STRUCT & 4,768 & $1.1 \%$ & 5 & 6.3 \\
\hline & Chemical engineering & JOURNAL OF MEMBRANE SCIENCE & J MEMBRANE SCI & 4,500 & $1.6 \%$ & 6 & 6.5 \\
\hline & Industrial biotechnology & BIOMATERIALS & BIOMATERIALS & 4,290 & $1.2 \%$ & 6 & 6.6 \\
\hline & Electrical eng, electronic eng & IEEE TRANSACTIONS ON INDUSTRIAL ELECTRONICS & IEEE T IND ELECTRON & 4,131 & $2.2 \%$ & 3 & 4.5 \\
\hline & Materials engineering & LANGMUIR & LANGMUIR & 4,074 & $0.7 \%$ & 7 & 7.0 \\
\hline & Materials engineering & JOURNAL OF THE AMERICAN CERAMIC SOCIETY & J AM CERAM SOC & 3,926 & $0.5 \%$ & 4 & 11.5 \\
\hline & Civil engineering & ENGINEERING STRUCTURES & ENG STRUCT & 3,923 & $1.1 \%$ & 4 & 5.8 \\
\hline & $\begin{array}{l}\text { Other engineering and } \\
\text { technologies }\end{array}$ & $\begin{array}{l}\text { JOURNAL OF MATERIALS PROCESSING } \\
\text { TECHNOLOGY }\end{array}$ & J MATER PROCESS TECH & 3,870 & $0.8 \%$ & 6 & 6.7 \\
\hline & Electrical eng, electronic eng & IEEE TRANSACTIONS ON POWER ELECTRONICS & IEEE T POWER ELECTR & 3,663 & $2.6 \%$ & 2 & 5.2 \\
\hline & $\begin{array}{l}\text { Other engineering and } \\
\text { technologies }\end{array}$ & JOURNAL OF FOOD SCIENCE & $\mathrm{J}$ FOOD SCl & 3,506 & $0.2 \%$ & 17 & 18.6 \\
\hline & Materials engineering & APPLIED SURFACE SCIENCE & APPL SURF SCI & 3,413 & $2.4 \%$ & 3 & 4.5 \\
\hline & Materials engineering & JOURNAL OF ALLOYS AND COMPOUNDS & J ALLOY COMPD & 3,395 & $3.6 \%$ & 3 & 3.6 \\
\hline & Materials engineering & CARBON & CARBON & 3,387 & $1.8 \%$ & 7 & 6.9 \\
\hline & Materials engineering & NANO LETTERS & NANO LETT & 3,349 & $1.1 \%$ & 6 & 4.6 \\
\hline & Materials engineering & CHEMISTRY OF MATERIALS & CHEM MATER & 3,335 & $0.2 \%$ & 6 & 7.6 \\
\hline
\end{tabular}


Appendix B: List of Top 20 Journals in Natural Science and Engineering (based on Co-citation Network Centrality, Degree Sum)

\begin{tabular}{|c|c|c|c|c|c|c|c|}
\hline $\begin{array}{l}\text { Main } \\
\text { Category }\end{array}$ & Mid-Category & Journal Title & Abbreviated Journal Title & degree & $\begin{array}{c}\text { weighted } \\
\text { degree }\end{array}$ & $\begin{array}{l}\text { Closeness } \\
\text { centrality }\end{array}$ & $\begin{array}{l}\text { Betweenne } \\
\text { ss centrality }\end{array}$ \\
\hline \multirow{20}{*}{$\begin{array}{l}\text { Natural } \\
\text { Science }\end{array}$} & Other natural sciences & SCIENCE & SCIENCE & 5091 & 12713.3 & 0.8 & 0.07557 \\
\hline & $\begin{array}{l}\text { Earth and related environmental } \\
\text { sciences }\end{array}$ & ECOLOGICAL ECONOMICS & ECOL ECON & 4899 & 10576.1 & 0.7 & 0.06591 \\
\hline & Other natural sciences & $\begin{array}{l}\text { PROCEEDINGS OF THE NATIONAL ACADEMY OF } \\
\text { SCIENCES OF THE UNITED STATES OF AMERICA }\end{array}$ & P NATL ACAD SCI USA & 4668 & 10020.3 & 0.7 & 0.06114 \\
\hline & Biological sciences & JOURNAL OF BIOLOGICAL CHEMISTRY & $\mathrm{J} \mathrm{BIOL} \mathrm{CHEM}$ & 3471 & 10324.5 & 0.6 & 0.01087 \\
\hline & Biological sciences & $\begin{array}{l}\text { BIOCHEMICAL AND BIOPHYSICAL RESEARCH } \\
\text { COMMUNICATIONS }\end{array}$ & BIOCHEM BIOPH RES CO & 2985 & 3344.2 & 0.6 & 0.00579 \\
\hline & Chemical sciences & ANALYTICAL BIOCHEMISTRY & ANAL BIOCHEM & 2601 & 2165.2 & 0.6 & 0.00354 \\
\hline & Chemical sciences & ANALYTICAL CHEMISTRY & ANAL CHEM & 2533 & 2850.0 & 0.6 & 0.00491 \\
\hline & Other natural sciences & $\begin{array}{l}\text { ANNALS OF THE NEW YORK ACADEMY OF } \\
\text { SCIENCES }\end{array}$ & ANN NY ACAD SCI & 2513 & 784.2 & 0.6 & 0.00647 \\
\hline & Biological sciences & FEBS LETTERS & FEBS LETT & 2509 & 1934.3 & 0.6 & 0.00313 \\
\hline & Chemical sciences & $\begin{array}{l}\text { JOURNAL OF THE AMERICAN CHEMICAL } \\
\text { SOCIETY }\end{array}$ & J AM CHEM SOC & 2496 & 7304.2 & 0.6 & 0.00548 \\
\hline & Biological sciences & NUCLEIC ACIDS RESEARCH & NUCLEIC ACIDS RES & 2492 & 2528.4 & 0.6 & 0.00470 \\
\hline & Other natural sciences & NATURE & NATURE & 2490 & 1649.0 & 0.6 & 0.00491 \\
\hline & Biological sciences & BIOCHEMICAL JOURNAL & BIOCHEM J & 2354 & 1666.7 & 0.6 & 0.00219 \\
\hline & Other natural sciences & PLOS ONE & PLOS ONE & 2236 & 651.1 & 0.6 & 0.00376 \\
\hline & $\begin{array}{l}\text { Earth and related environmental } \\
\text { sciences }\end{array}$ & ENVIRONMENTAL SCIENCE \& TECHNOLOGY & ENVIRON SCI TECHNOL & 2196 & 4501.4 & 0.6 & 0.00436 \\
\hline & Biological sciences & FASEB JOURNAL & FASEB J & 2136 & 993.9 & 0.6 & 0.00187 \\
\hline & Biological sciences & PHYTOCHEMISTRY & PHYTOCHEMISTRY & 2101 & 1939.0 & 0.6 & 0.00238 \\
\hline & Chemical sciences & IOUURAL OF CHROMATOGRAPHY A & J CHROMATOGR A & 2101 & 2037.1 & 0.6 & 0.00251 \\
\hline & Biological sciences & BIOCHEMISTRY & BIOCHEMISTRY-US & 2097 & 1529.0 & 0.6 & 0.00148 \\
\hline & Biological sciences & MOLECULAR CELL & MOL CELL & 1987 & 1669.0 & 0.6 & 0.00144 \\
\hline \multirow{2}{*}{$\begin{array}{l}\text { Engineering } \\
\text { and } \\
\text { Technology }\end{array}$} & Environmental biotechnology & $\begin{array}{l}\text { APPLIED AND ENVIRONMENTAL } \\
\text { MICROBIOLOGY }\end{array}$ & APPL ENVIRON MICROB & 2663 & 6155.7 & 0.6 & 0.00619 \\
\hline & $\begin{array}{l}\text { Other engineering and } \\
\text { technologies }\end{array}$ & FOOD CHEMISTRY & FOOD CHEM & 2343 & 4788.8 & 0.6 & 0.00322 \\
\hline
\end{tabular}


Kim, B., Kim, Y. \& Kang, J.

\begin{tabular}{|c|c|c|c|c|c|c|}
\hline Industrial biotechnology & $\begin{array}{l}\text { BIOMATERIALS } \\
\end{array}$ & \begin{tabular}{|l} 
BIOMATERIALS \\
\end{tabular} & 2342 & $\begin{array}{llll}3358.4 \\
\end{array}$ & 0.6 & 0.00461 \\
\hline Environmental biotechnology & NATURE BIOTECHNOLOGY & NAT BIOTECHNOL & 2315 & 14990.1 & 0.6 & 0.00320 \\
\hline $\begin{array}{l}\text { Other engineering and } \\
\text { technologies }\end{array}$ & FOOD AND CHEMICAL TOXICOLOGY & FOOD CHEM TOXICOL & 2157 & 1405.1 & 0.6 & 0.00233 \\
\hline Environmental biotechnology & $\begin{array}{l}\text { APPLIED MICROBIOLOGY AND } \\
\text { BIOTECHNOLOGY }\end{array}$ & APPL MICROBIOL BIOT & 2136 & 2613.4 & 0.6 & 0.00231 \\
\hline $\begin{array}{l}\text { Other engineering and } \\
\text { technologies }\end{array}$ & $\begin{array}{l}\text { BIOSCIENCE BIOTECHNOLOGY AND } \\
\text { BIOCHEMISTRY }\end{array}$ & BIOSCI BIOTECH BIOCH & 2065 & 1705.5 & 0.6 & 0.00170 \\
\hline Environmental biotechnology & $\begin{array}{l}\text { JOURNAL OF MICROBIOLOGY AND } \\
\text { BIOTECHNOLOGY }\end{array}$ & J MICROBIOL BIOTECHN & 1962 & 1877.4 & 0.6 & 0.00153 \\
\hline Environmental biotechnology & $\begin{array}{l}\text { BIOTECHNOLOGY AND BIOENGINEERING } \\
\end{array}$ & BIOTECHNOL BIOENG & 1934 & 1701.9 & 0.6 & 0.00186 \\
\hline Materials engineering & LANGMUIR & LANGMUIR & 1920 & 3440.6 & 0.6 & 0.00221 \\
\hline \begin{tabular}{|l|} 
Civil engineering \\
\end{tabular} & JOURNAL OF HAZARDOUS MATERIALS & J J HAZARD MATER & 1871 & 4218.3 & 0.6 & 0.00312 \\
\hline Environmental biotechnology & TRENDS IN BIOTECHNOLOGY & TRENDS BIOTECHNOL & 1840 & 798.1 & 0.6 & 0.00155 \\
\hline Medical engineering & CLINICAL CHEMISTRY & CLIN CHEM & 1772 & 621.1 & 0.6 & 0.00166 \\
\hline Environmental biotechnology & JOURNAL OF BIOTECHNOLOGY & J BIOTECHNOL & 1749 & 1108.1 & 0.6 & 0.00123 \\
\hline $\begin{array}{l}\text { Other engineering and } \\
\text { technologies }\end{array}$ & JOURNAL OF FOOD SCIENCE & J FOOD SCI & 1682 & 2779.7 & 0.6 & 0.00159 \\
\hline Chemical engineering & PROCESS BIOCHEMISTRY & PROCESS BIOCHEM & 1640 & 1805.6 & 0.6 & 0.00101 \\
\hline $\begin{array}{l}\text { Other engineering and } \\
\text { technologies }\end{array}$ & FOOD SCIENCE AND BIOTECHNOLOGY & FOOD SCI BIOTECHNOL & 1631 & 1734.2 & 0.5 & 0.00094 \\
\hline $\begin{array}{l}\text { Other engineering and } \\
\text { technologies }\end{array}$ & $\begin{array}{l}\text { JOURNAL OF BIOSCIENCE AND } \\
\text { BIOENGINEERING } \\
\end{array}$ & J BIOSCI BIOENG & 1619 & 759.9 & 0.6 & 0.00086 \\
\hline Chemical engineering & $\begin{array}{l}\text { INDUSTRIAL \& ENGINEERING CHEMISTRY } \\
\text { RESEARCH } \\
\end{array}$ & IND ENG CHEM RES & 1606 & 2635.8 & 0.6 & 0.00244 \\
\hline Environmental biotechnology & ENZYME AND MICROBIAL TECHNOLOGY & ENZYME MICROB TECH & 1593 & 1486.3 & 0.5 & 0.00098 \\
\hline
\end{tabular}

